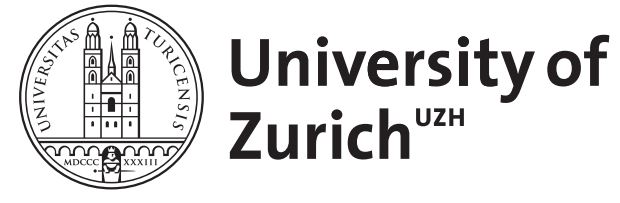
Archive

University of Zurich

University Library

Strickhofstrasse 39

CH-8057 Zurich

www.zora.uzh.ch

Year: 2000

\title{
Electronic meeting support for councils
}

Schwabe, Gerhard ; Krcmar, Helmut

DOI: https://doi.org/10.1007/BF01206128

Posted at the Zurich Open Repository and Archive, University of Zurich

ZORA URL: https://doi.org/10.5167/uzh-61307

Journal Article

Accepted Version

Originally published at:

Schwabe, Gerhard; Krcmar, Helmut (2000). Electronic meeting support for councils. AI and Society, 14(1):48-70.

DOI: https://doi.org/10.1007/BF01206128 


\title{
Electronic Meeting Support for Councils
}

\author{
Gerhard Schwabe, Institut für Wirtschaftsinformatik, University of Koblenz-Landau \\ Helmut Krcmar, Lehrstuhl für Wirtschaftsinformatik, Hohenheim University
}

\section{Summary}

City councils hold meetings several times a week. There is a need for computer support at certain meetings. This paper examines the potential for group support systems for use in city council meetings and shows in which ways they can be helpful in pre-meeting and post-meeting activities. This study is based on 17 computer supported city council meetings. They were carried out in Stuttgart, Kornwestheim and other cities as part of the Cuparla Project between 1996 and 1998. Three of these meetings are described in the paper as brief case studies. Following this, all 17 meeting sequences are evaluated and analyzed. From this analysis we deduct some guidelines for the introduction of group support systems to city council meetings.

\section{Introduction}

Politicians are decision makers. In spite of their importance, their work has not changed very much for decades. The opportunities for improvement in the work of individuals and teams which are offered by the new information and communication technology in particular are not being introduced to the same extent as is the case in business or public administration. This is justified by the special sensitivity of politics. Computer systems are only used in the less sensitive fringe areas, for example, in an individual's office work, a presentation in the Internet or when searching for information. The "holiest of holies" among politicians - council meetings - have till now abstained from using them although, especially in this area, a lot of time is wasted and there is little productive work. The support of the meetings for politicians is therefore one of the organizational and technical innovations which is advanced in the Cuparla Project (Computer Support for Parliamentary Work ${ }^{1}$ ).

The Cuparla Project supports close cooperation within the city councils in Stuttgart and Kornwestheim. To this end, 56 of the 60 Stuttgart city councilors and 20 of the 26 city councilors from Kornwestheim were equipped with mobile telecooperation technology. This technology is based on a Lotus Notes application developed specially for them and on GroupSystems. Thus, the synchronous and asynchronous cooperation can be supported in the meetings as well as outside and at home. The subject of this article is the electronic support of meetings. The text is built up in the following manner: at the beginning reference is made to related works with a short literature review. Then we examine meetings as part of the work of the city council, in order to identify the demand for the introduction of a Group Support System (GSS) for their meetings. Then various design options are described for political meetings using Group Support Systems. These design options are illustrated by three case studies. 17 meeting sequences are analyzed, each consisting of 1 - 3 computer supported council meetings. This analysis leads to recommendations for the introduction of GSS into council work.

\footnotetext{
${ }^{1}$ Commissioned by German Telekom Berkom GmbH, the Cuparla Project has been carried out (1995-1997) by the University of Hohenheim (the project co-ordinator), the Datenzentrale Baden-Württemberg and ITM GmbH.
} 


\section{Related work}

Research on GSS and their effect on groups has been conducted since the mid eighties in the USA and since the end of the eighties in Germany [Krcmar 1992]. Nunamaker et al.[1991] have presented a survey of research findings for the eighties. The experimental results were summarized by Lewe [1995]; a synopsis of CSCW tools is to be found in [Schwabe \& Krcmar 1996]; general recommendations for the design of computer supported council meetings and a description of Group Support Systems are to be found in [Schwabe 1994, Schwabe 1995]. The Group Support System GroupSystems used in the council meetings is described in [Dennis et al.1988] and [Lewe \& Krcmar 1992].

Computer support for cooperation in the German public administration has at this time been promoted in particular within the framework of the Polikom projects of the BMBF. The Polikom projects focus on bridging the distance between Bonn and Berlin. The Polikom project Poliwork [Bever et al. 1996, Engel et al.1997] implements a support system for small discussion groups in the public administration. In this project, however, video conference systems were preferred rather than support by the GroupSystems used in Cuparla. Like the Cuparla project the Polivest project functions in a political environment. It provides support for the Bundesrat [Dietel et al.1997, Reichwald et al. 1998 p. 199ff] providing information for the representatives of the individual Federal States in Bonn.

We are not aware of any computer support for political decision-making in any of the Polikom projects. We only know of two projects from Scandinavia concerned with this subject:

1. In Denmark ordinary citizens developed the guiding principles of Danish government on the information society in a series of GroupSystems workshops. Krcmar [1997] speaks about 100 participants. This successful operation is in line with the recognised efforts in the USA to introduce public participation in government [Schuler 1996]. American public participation is, however, normally based on electronic discussion groups in the Internet.

2. The work of diplomats at a subsequent Helsinki conference was to have been supported by GroupSystems [Lyytinen et al. 1992]. The plan was worked out, the meeting rooms prepared but their use was declined by the diplomats since their negotiations were regarded as too sensitive.

The Cuparla Project is comprehensively discussed in [Schwabe 1998]. Aims and the creation of the Cuparla project are presented in [Schwabe \& Krcmar 1996b]; the development of Notes-Software in [Schwabe et al.1997]. Schwabe and Vöhringer [1998] present the information on the organizational implications of Cuparla for the management of the City of Stuttgart; Schwabe [1998b] elucidates the management of information for the City Council, [Schwabe 1999] analyses organizational memory and knowledge management issues.

\section{Meetings as part of political work}

Political work is for the most part carried out in meetings; city councils make their decisions at meetings. These decisions are prepared in party and committee meetings as well as informally. In 1996 the City Council met 23 times and the meetings lasted 47 hours in all. There were 142 meetings for the decision-making committees lasting altogether 404 hours [Borgman 1997]. A meeting of the administrative and finance committee lasted on average (!) seven hours. In the spring of 1996 we measured the city council's work load asking the council members to record their time 
allocation. A councilor spent 2.7 hours each working week ${ }^{2}$ in plenary sessions, 7.3 hours sitting on committees and advisory boards, 2.8 hours at party meetings and 7.2 hours on preparation before and after meetings. That means 20 hours a week revolve round the subject "meetings for city council work".

Councilors do not regard the meetings as productive. An analysis of the meetings shows why. One main problem is that the meeting process has been standardized for all the different types of meetings and issues: a typical meeting has an agenda with more than 10 items per hour. These items on the agenda are announced by the Chairman, the item's proposer provides background information, the representatives of the different parties (or interested groups within the party) express their opinions. Then follows a discussion which closes with a final proposal by the Chairman and the subsequent vote. These meetings require a firm leadership because most meetings have many participants. 60 people can take part in one City Council meeting, 17 people sit on a committee, and, depending on the strength of the party, between four and 20 people in a party meeting. Individuals have very little air time.

\section{Design Options}

We will now introduce the design options open for computer-support in political committee work. They are based on three sources: the main source is from 17 computer-supported meetings which were carried out by the Cuparla Project with the Stuttgart City Council and other city councils. Three of these meetings will be dealt with in this chapter. Furthermore we continuously evaluated the work and the needs of the Stuttgart and Kornwestheim city council members using qualitative and quantitative instruments. These analyses of the work and needs of the city councils were obtained using the Needs Driven Approach method [Schwabe \& Krcmar 1996c] and were written up in a joint project diary. The third source consists of concrete suggestions made by individual city councilors.

There are several starting points for the improvement of council meetings:

1. Small discussions can be transferred from meetings to other forums in order to obtain time for more important debates. Stuttgart's mayor Schuster favors this action using the motto: "Focus on essential City Council work". Many decisions are transferred from the plenary meeting to a committee; the City Council then only has to take a final vote on them. The extra time thus gained is used for major debates. This method, however, merely transfers the meeting problems from one group to another. The total productivity would increase if all the work were transferred from the plenary or the committee to other media e.g. electronic news groups.

2. In addition to verbal discussions, other channels of communication and media can be used for team work. For example, flip charts can be used to keep the group concentrated on the subject throughout the meeting. Written work with cards which are stuck on wall charts can raise members' participation levels because at this stage participants can work in parallel. The application of these media is well known through structured problem solving techniques like the Metaplan method [Schnelle \& Schnelle 1984] or the "Moderation method" [Klebert et al. 1985]. Schwabe [1995] has

\footnotetext{
${ }^{2}$ therefore not in school holidays
} 
developed a comprehensive concept for the application of new computer-supported channels of communication and media in meetings.

3. Using a systematic methodology to prepare meetings, the meeting process is deducted from the results desired from the meeting: The result of the whole meeting and of individual subjects is defined beforehand in its form and intended effect (e.g. information from the participants, discussion about opinions or decisions). Then those structured problem solving techniques are chosen which will lead the group to the required result. Thus, meetings need not be conducted merely according to one standard plan but can be arranged creatively and in accordance with the problems under discussion. New channels of communication and media enhance the spectrum of potential beneficial process interventions.

4. Follow-up work after the meeting should be improved: The results of the meeting should be electronically recorded, indexed and filed for general use (for details see [Schwabe 1999]). They are then available to the individual councilor any time and any place.

During discussions on the work at city council meetings, it transpired that the use of one standard scheme for all types of meetings is really a problem for the traditional city council work. A standard scheme for all types of meetings cannot accordingly be the aim for designing computer-supported meetings. A comprehensive design must take the type of meeting into account. Building on the experience gained during the recent computer-supported meetings in Stuttgart, the three following design options have been created: one for the weekly party meeting, one for the committee meeting and one for the workshop with public participation. These design options are illustrated in the four basic functions of groupware:

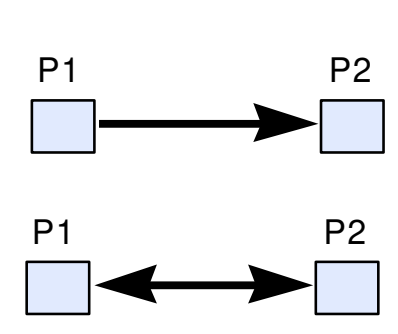

Information: One person (or one group of people) P1 supplies information 2 and a second group of people, P2, mostly larger and divided up, reads this information. There is no direct interaction between the two groups.

Communication: Two (or more) people P1 and P2 (....Pn) exchange news. The communicating partners are known to each other and have a relationship with each other.

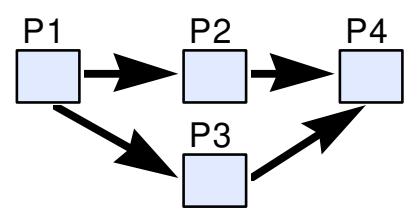

Coordination: Tasks dependencies are managed between actors (see [Malone \& Crowston 1994, p.90]) Actors are represented by P1, P2, P3, P4.

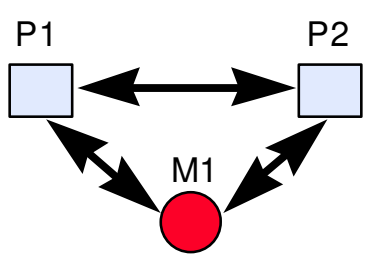

2 Cooperation: Cooperation is characterized by the joint creation of a product. Participants (P1, P2........Pn) work with shared material M1 and communicate on their own communication channel. 


\subsection{Political party meetings}

In their party meetings ${ }^{3}$ city councilors share the same basic convictions. Meetings therefore take place in a comparatively open and intimate atmosphere. Party meetings, however, are overburdened with tasks: they serve

- to define the party positions,

- to make one's mark within the party for their fellow city councilors,

- to work out ideas and initiatives together,

- to convey information from one councilor to another,

- to co-ordinate activities amongst council members (e.g. who participates in what event),

- to discuss problems,

- to constitute rules for internal organization, and

- to create a feeling of togetherness in the party.

The overburdening of party meetings with too many tasks conceals the danger that no task can be properly resolved. The principal aim in the design of party meetings must therefore be to transfer many of the formal activities from the party meetings to other forums and to bring the remainder of their activities into sharp focus. Groupware can support both:

Information: Party business relies very substantially on information. The difficulty in carrying out party business consists in the fact that a wealth of information is only available during party meetings, since most of the important know-how exists only in the minds of the party members. A lack of other sources of information makes the recall and the transmission of information one of the main tasks of traditional party meetings. If it is a matter of aspiring to reach a shared understanding of complex or context-sensitive matters, then the time given to it in a party meeting is a good investment. But if it is just a matter of imparting factual knowledge for individuals or sections of the party, the utilization of other media to transmit information is more productive. Digital information data bases can be built up and so become the core of information for party business. There can be digital blackboards or information bulletins for public announcements or notifications. For systematic storage a digital party archive can be created. Any councilor can, at any time and in any place, have access to this digital information. Party meetings abdicate a little of their unique standing as centers of information sharing.

Communication: Communication can be transferred from the party meeting to other media like email or asynchronous news groups, if only a minority of participants are interested, if it is just a matter of the transmission of data or if the communication is of permanent interest and should therefore be documented. In a party meeting the participation of individual members can be enhanced by simultaneous minutes (see the case study below).

Coordination: It is tempting to use a meeting for the coordination of activities; but it is not always necessary: the coordination of activities can just as well be carried out via digital media. For example, dates for public appearances can be offered to the party on an electronic market; interested clients can register themselves for these activities and visibly book them for all other city councilors. Or dates can be coordinated using an electronic group calendar. Good meetings are furthermore thoroughly prepared before the meeting. Most important, the agenda should be agreed on before the meeting. Asynchronous groupware systems are ideally suited to collect prospective agenda items beforehand and to announce the completed agenda.

\footnotetext{
${ }^{3}$ Legally, the German city council consists of 'factions', not 'parties'. In Stuttgart, the factions were created along party lines. In Kornwestheim, the two smallest parties have joined in one faction.
} 
Cooperation: Meetings are most productive when they are engaged in cooperation, i.e. in joining together in a creative exercise on a shared material. With large groups this is only possible with the introduction of facilitation techniques. These techniques can influence the meeting process in ways of varying intensity. A minor process intervention would be, for example, if the councilors were to vote electronically rather than use paperwork. If new voting practices were to result from this, e.g. a allocation of priorities to several subjects, this would be a moderate intervention. A moderate intervention would also be, for example, if, apart from the verbal discussion channel, a written discussion channel was opened up (vide example in this paragraph). A major process intervention would be the redesign of a meeting, in which points of view were exchanged, into a workshop in which the group is jointly involved in a structured process for reaching solutions. Such a workshop is described in greater detail under the heading "Public participation", but they were also carried out by us in closed political meetings on budgetary discussions.

The closed budget meeting of the Stuttgart SPD in 1996 can be quoted as an illustration of a successfully supported meeting. A major problem of past meetings had been that with the presence of 16 councilors and two mayors, individual participants had scarcely enough airtime to express their opinions. As, however, individual councilors insisted on having their say, discussion on many items on the agenda had to be interrupted without a satisfactory outcome being reached. The meetings came to an end, therefore, with two unsatisfactory aspects: firstly, individual councilors were frustrated in their attempts to air their views sufficiently and they were bored with the unending speeches by other councilors. Secondly, when the meeting finished, it was frequently not clear exactly what had been decided.

The technology of simultaneous minutes was introduced into this situation. Every participant received a notebook with the Group Support System GroupSystems. On this notebook the participants shared an electronic outline. The top items of the outline were the agenda items of the meeting. The meeting was conducted quite normally except for one important alteration. In addition to the verbal discussion channel, the shared outline served as a written discussion channel. Using the written channel the councilor could comment on previous agenda items, announce a statement for future agenda items or just express in writing his opinion about the current agenda item. These choices were taken up by the participants particularly whenever they found the current speaker boring. The party assistant took the minutes of all verbal contributions. Therefore, there was a record of the meeting available during the meeting for all participants. Towards the end of the meeting, the participants made use of this record to pinpoint items still unsettled (the assistant having identified them as such) and to systematically take all the necessary resolutions. Thereby, not only the participation of the councilors could be enhanced by a comparatively modest introduction of technology but clear decisions could also be taken ${ }^{4}$.

\subsection{Committee Meetings}

Committees are parliaments in miniature. All the political parties are represented there in order to prepare decisions on certain subject matters and also to finalize lesser decisions. In practice they have a double role: on the one hand they are still useful for objective work i.e. an objective compromise can be reached in the committee meeting specially for lesser demands. On the other

\footnotetext{
${ }^{4}$ In this meeting the system also made use of the technology, to compose written jokes and Spoonerisms, making the whole group laugh, partly at the expense of the external experts who had been invited to attend!
} 
hand they are useful for politicians who wish to improve their image - especially if there is an important item or if the public are taking part in the debate. In this case the parties go to the committee meeting with preconceived opinions, present it together with their arguments and decide by vote.

Furthermore, committee meetings are also overloaded with subjects, especially in Stuttgart, because more and more work is being transferred to them from plenary sessions. Items on the agenda are quickly dispatched and often the committee does not reach a joint decision because there does not seem to be enough time. Any electronic support supplied for committee work has to rid their meetings of as much "ballast" as possible and use the remaining time as efficiently as possible. "Ballast" can, for example, be requests for information about the stage reached in various work or admonitions to the administration. There should definitely be time in the committee work for opinions to be expressed; purely factual information should however be removed if it does not concern a complex situation. The special political sensitivity at committee meetings suggests a cautious application of groupware for the expression of opinions. For objective work groupware can be of use in the following areas:

Information: The main problem is the presentation of the right kind of information. This information should be extracted from the strategic managerial process and not just from isolated individual episodes [cf. Schwabe \& Vöhringer 1998]. The latter leads to an information overload with fragmented information. The city council and the administration are equally responsible for the fragmentation of information at that point, for the administration does not like to show its hand and the city councilors like to win points with individual groups of people when they show that they care about very specific problems (e.g. a clattering manhole cover). As this problem touches the identity of the council, it can only partially be solved by digital media: Electronic data bases provide information presented in the form of isolated decision documents, enquiries and minutes. An additional layer of links on top of these documents may structure the information. Indexes may simplify information search. Both make it easier for council members to deal with the fragmented information.

Communication: Asynchronous electronic communication is especially suitable for short electronic enquiries for factual information. It is furthermore conceivable that a second channel could be opened up in the committee meetings for synchronous written communication. However, because political parties oppose each other in the meetings, the second channel cannot be used for shared minutes like in internal party meetings. But a sensible use is coordination within the political parties e.g. in order to agree on a common voting practice or on the strategy for a further debate. In this way, by using the electronic channel coalitions can even be formed ad hoc between the different parties in the meetings.

Coordination: Committee work is especially impeded by three coordination problems: firstly, the agreement on dates for the meetings, secondly, the coordination of tasks among councilors on various committees and thirdly, the allocation of time to agenda items. The first problem, for example, becomes obvious only when individual city councilors have double appointments - as city councilor on a committee and at the same time as representative of their city on a board of directors. The coordination of appointments can be improved with the use of a group calendar.

Coordination difficulties within a party become obvious if the same party is found to have evaluated the same matter differently in different committees. This generally means that representatives in the 
committees have not discussed it enough. If the administration publishes electronic short minutes immediately after the meeting, council members of later committee meetings are at least aware of their colleagues previous voting behavior. The same could be achieved, if the council members themselves publish their voting behavior in their party.

The image of the individual city councilor depends on his airtime. The committee chairman is responsible for a fair allocation of speaking time. The allocation of speaking time can be supported by electronic tools. The councilors announce their contribution using these tools. At best they can show the chairman what the contribution relates to (e.g. either to the previous speaker or to the subject matter in general) and what form the contribution takes (question, short comment, detailed speech) and how long the contribution will be. If the speakers give notice of contributions not merely for the current item but for all agenda items, then the chairman can also estimate how much time each agenda item requires. Only by such careful planning can they prevent mayors, departmental managers, town hall employees and freelance experts having to wait for hours outside the committee room until each person's relevant subject is called. Since the summer recess of 1997 an attempt has been made to plan the exact length of a meeting by keeping strictly to the time allocated for the whole discussion on each item on the agenda. Electronic announcements of speakers' contributions both before and during the meeting can introduce more flexibility into the proceedings.

Cooperation: The "shared material" in traditional committee meetings are the documents and proposals as well as the speakers' contributions. However detailed the facts of the decisions are laid out in the documents, the decisions may need to be changed during the meeting. Paper documents are too inflexible for these immidiate changes in the meeting. In traditional meetings, the parties concerned discuss the alterations verbally. Should these alterations be relatively simple, they trust the person taking the minutes to set it down correctly on paper later; should they be complicated, then the administration is asked to work out a new proposal based on the contributions and in this way the decision will be adjourned. It is useful if the shared material used in the meeting can be manipulated by the group. If, for example, suggestions for wordings are shown on a giant screen during the meeting and can be changed by any participant. Then more complicated alterations $\mathbf{b}$ final documents can still be made during the meeting.

Joint voting in meetings also presents a problem for the Stuttgart city council. For one thing, there are the reasonably trivial problems where, again and again, more votes are counted than there are councilors in the chamber entitled to vote. Then the vote has to be taken again, occasionally several times. These problems can be solved using an electronic voting machine. A far bigger problem regarding the quality of the decisions is that, when voting, they can only vote for or against something. More complicated decision-making procedures like, for example, a prioritization of issues, cannot be done manually because of the effort of vote counting (each council member has to work out his priorities and from these the priorities of the group have to be calculated); in a computer-supported meeting, this is, however, no problem. For example, the decisions taken on expenditure in the budget discussions could be passed more expediently in this manner.

If important subjects are to be dealt with comprehensively altogether in meetings, then it is possible to change the meeting into a workshop. In a workshop the participants collaborate using structured problem solving techniques [van Gundy 1988] and the meeting process is facilitated. As an example 
of such a committee meeting, let us consider a recent meeting of the equal opportunities advisory committee ${ }^{5}$.

The meeting had only one subject: The new design for the Inner City, fair and friendly for women, which i to be created within the framework of Project Stuttgart 21. For this topic the participants had set aside 2.5 hours plus breaks. In these 2.5 hours they first of all collected ideas using electronic brainstorming and then organized them so that they had a complete understanding of the problem. Then, in a second brainstorming, they collected their demands for Stuttgart 21 and picked out the most important ones. Finally, they organized their demands into a common construction plan for the problem areas. In this way they were able to present their joint demands to the city in a structured form. It was stressed that the biggest advantage of an electronic meeting was that the discussion was more rational with the anonymous contributions and that the participants' contributions had been kept brief. In this way they had saved a lot of time.

\subsection{Workshops with public participation}

Politicians wish to make contact with citizens. One form of public participation is workshops, in which politicians and people work out together their political ideas on the wider subjects of civic administration. These ideas were tried out as long ago as the Seventies under the heading of "Planning Cell" [Dietel 1991]. If a large group wishes to work together productively over a fairly long period of time, their collaboration processes need to be moderated by a professional facilitator. A group support systems can support the facilitator in making the participants' meeting process more productive. Groupware can also support the provision of information, communication and coordination:

Information: As great as the demands on the people's general understanding in the workshops may reach, background information can, nevertheless, be profitable in helping to clarify factual issues. This information can be placed electronically at the disposal of the participants before the workshop takes place, during the workshop and during any breaks. Access can be provided through the Internet or the city council administration's intranet. Electronic information provision may be especially profitable if a trained information broker researches the information professionally and the participants are not distracted from the business of the meeting by having to search for information.

Communication: Public participation in workshops is necessarily limited within a given time; what is desired, however, is continuous contact with "active citizens" in the community. A step in the direction towards more continuity and less time restriction has been taken when people's workshops are prepared beforehand and afterwards in electronic newsgroups. This appears to be more productive than to shift the discussion completely onto the Internet.

Coordination: The coordination of citizens' workshops is a time-consuming exercise for the organizers in respect of four considerations: firstly, when it concerns winning over prospective participants; secondly, whenever joint activities require follow-up work; thirdly, whenever participants have to divide into subgroups during the workshops and fourthly, whenever these subgroups have to co-ordinate their work with one another. In the first three instances it is helpful if an electronic market place is opened up with the aid of shared material and the participants coordinate with this shared material. This shared material can be a simple list of topics in which every participant

\footnotetext{
${ }^{5}$ The authors express their gratitude to Herrn Dieter Hertweck for the facilitation and documentation of this case history.
} 
registers according to his interests. As the registration lists is public, each prospective participant is aware of other prospective participants and their interests. When the subgroups work with a major shared material (e.g. a map or an outline), then they can co-ordinate their activities themselves, since they have no difficulty in informing themselves about the work situation of other groups (as it is represented on the shared material).

Cooperation: The purpose of workshops is centered primarily on cooperation; this is where the advantages of computer support systems really comes into its own: the higher productivity through parallel work, the improved documentation of results and reusability of provisional results, enhanced participation because of the possibility of being an anonymous contributor and the enhanced rationality of the meeting process. That is to be illustrated shortly by the example of a meeting which took place within the framework of the Stuttgart Agenda 21 process. You will find a detailed analysis of this meeting in Schenk \& Schwabe [1998].

The Green Party invited altogether over 60 people for four hours on two evenings and finally for eight hours all day on a Saturday to work out a concept for "A healthy Stuttgart". 55 people took part. The meeting was conducted by a freelance professional moderator and supported by a facilitator from the Cuparla project. They organized the work in keeping with the methods employed in the "Future Search Conference". The method was developed for grassroots democracy work groups. Non-centralized self-led subgroups work out their ideas on a subject and then get together at regular intervals in the plenum to exchange their provisional conclusions. In doing so, all subgroups run through the same work program. First "the past" of the subject is discussed, then "the present" and, in the third stage, "the future", and then finally an attempt is made to obtain agreement on measures to be taken. To avoid intellectual inbreeding, the sub-groups are made up differently at separate stages.

In this meeting networked notebooks were distributed on the work tables in such a way that about every second participant had a notebook. For a typical work group with six people three notebooks were therefore available. No more notebooks were available. This did not, however, prove to be a disadvantage in the meeting. It meant that participants who had no computer expertise could share a notebook with those who possessed either more knowledge or more confidence. The participants shared one big electronic outline. The top headings of the outline were the names of the subgroups; each subgroup thus had its own area for collaboration to use at their own disgression and still be aware of what the other subgroups were doing. All the sub-groups used the notebook for the documentation and presentation of their conclusions; some sub groups divided once again for separate phases (e.g. brainstorming) into three mini-groups of two and thus enhanced the internal productivity of their group through parallel work. The participants adapted themselves rapidly to the technology and missed it in the phases in which it was not utilized. In conclusion, they considered, by a large majority, the utilization of computers to be a success; the lady city councilor who organized the meeting regarded the result in the best light: because of the existing electronic documentation, she found it distinctly easier to summarize the results and pass them on to the council members.

\section{A comparative analysis of computer-supported meetings}

Between Autumn 1996 and Spring 199817 computer-supported meeting sequences in the political and municipal confines of Stuttgart, Kornwestheim and other cities were carried out. The meetings 
were supported either in the city hall by the mobile CATeam environment ${ }^{6}$, or they took place in the Hohenheim CATeam Room. The meetings covered a wide spectrum of subjects, meeting pro??cesses, and participants.

The following sections introduce an evaluation framework. Then we evaluate the meetings and analyze the findings.

\subsection{Evaluation Framework}

The analysis of computer-supported meetings requires a framework with evaluation criteria. The framework adapts the Electronic Meeting Systems evaluation framework of Dennis et al. [1988] to our needs.

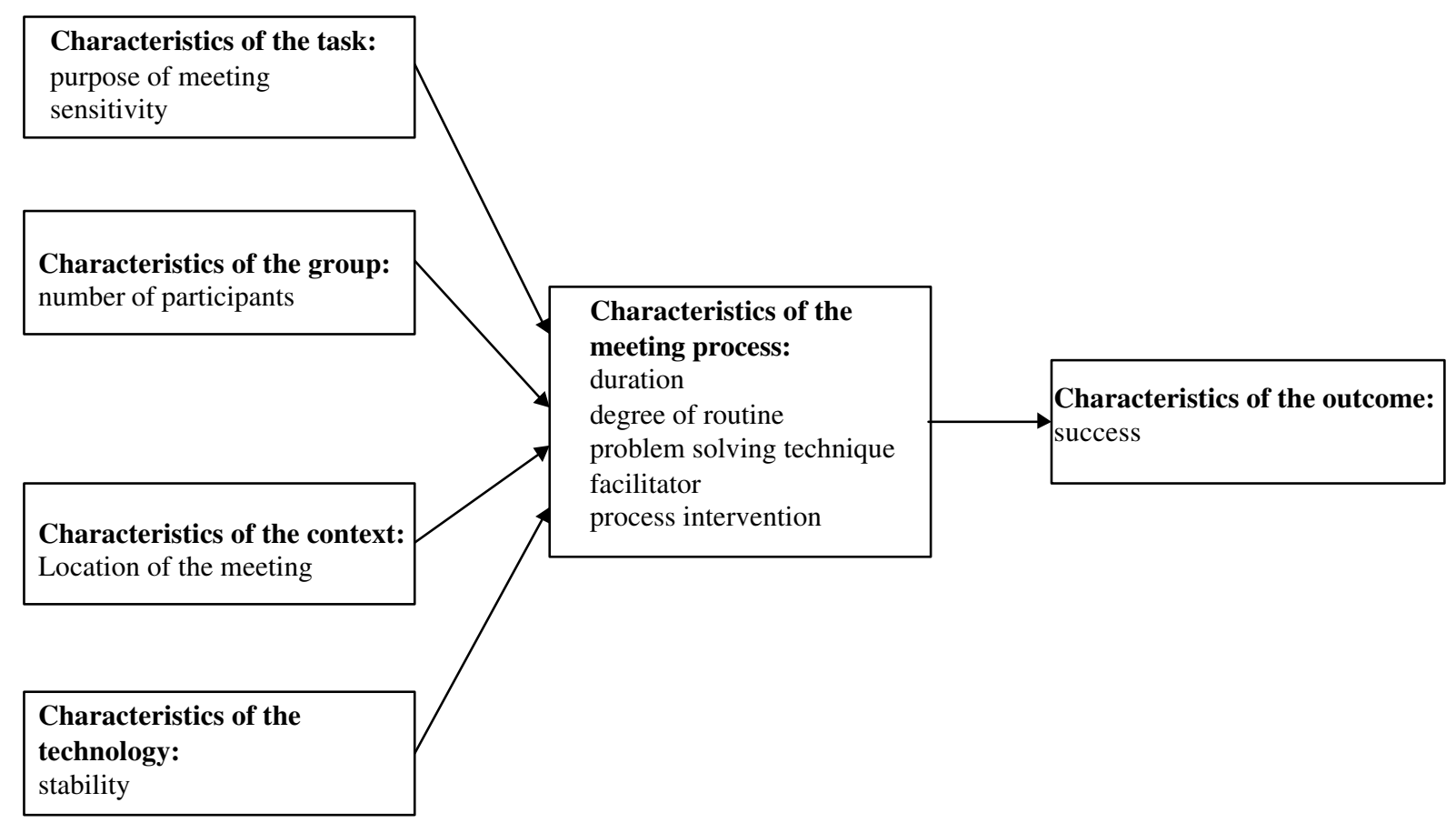

\section{Figure 1: Evaluation Framework}

The left hand side of the evaluation framework summarizes the input to the meeting process; the middle depicts the meeting process itself and the right hand side shows the degree of "success" as the only outcome measure. We will now briefly motivate and explain the variables:

a) Characteristics of the task

- Purpose of meeting: Initiators of the meeting can be the University or the council. The University can call the councilor to a meeting to extract requirements for their support or to evaluate the computer system in place. The councilors can invite other councilors to computer supported party meetings, committee meetings, budget deliberations or to collaborate with citizens on local issues. We were interested, how the involvement of the council members in the matters discussed would influence the acceptance of technology and ultimately the meeting success.

- Sensitivity: With the phrase political "sensitivity" is meant the opportunity or the risk for the participants that their convictions and heartfelt opinions can be challenged in public, if the occasion arises, or they have to revise their opinions and then their political careers may be permanently damaged. For example, an internal party planning meeting is characterized as one of

\footnotetext{
${ }^{6}$ A mobile CATeam environment consits of networked notebooks and the Group Support System GroupSystems.
} 
great political sensitivity, whereas public participation meetings like the Local Agenda 21 are from the political point of view, not so sensitive, since only guide lines are laid down. The sensitivity of the subjects which are dealt with in the meeting, has corresponding consequences on the successful use of computers: First of all, it is to be presumed that a suitable trusting relationship must exist between the facilitators and the participants of the meeting, above all with the heads of the meetings and secondly, there should exist amongst the participants a certain familiarity with the tools that are used in order to make it easier to concentrate upon the subject matter.

b) Characteristics of the group

- Number of participants: Larger groups traditionally tend to benefit more from GSS but they also pose a greater challenge to the facilitator.

c) Characteristics of the context

- Location of the meeting: Meetings could take place in Hohenheim, in the city hall and at external locations. We assumed that the location of the meeting would influence the behavior of the councilors.

d) Characteristics of the technology

- Stability: All meetings were run using the GSS GroupSystems. GroupSystems can become unstable, particularly if it is used in an unreliable network (as frequently exists in ad-hoc networked notebooks). Unstable technology leads to meeting interruptions and ultimately to a breakdown of the meeting process.

e) Characteristics of the meeting process

- Duration: The longer a meeting lasts, the more time the participants have to appropriate new technology and new meeting processes. We were interested, how this would influence outcome.

- Routine: Almost all committee meetings follow the same procedure. As they occur at least once a week, they are a highly routine business for the experienced councilors. On the other hand most councilors rarely participate in citizens workshops. Furthermore these citizens workshops can have different meeting processes. Therefore citizens workshops have little routine character for the councilors. We were interested, if GSS were more beneficial to highly routine meetings or if it is easier to introduce new technology into new types of meetings.

- Facilitator: The meeting process can be facilitated by an external facilitator, by a group member or by a team of the two. We experimented with all three styles in order to find out, which one was more successful for what type of meeting.

- Problem solving technique: We used the following problem solving techniques:

Workshop: In a workshop participants work out a solution to a problem together. Facilitation techniques are used and the meeting is subdivided into various phases for solving the problems (e.g. generate ideas, consolidation, assessment, make up to-do-lists). The computerbased materials are used like Metaplan materials (small cards, wall charts..).

Electronic discussions and assessment: The meeting process follows its traditional course but instead of verbal discussion and assessment, these are now both computer-supported.

Simultaneous minutes: The conventional proceedings of the meeting are supplemented by a written channel. The discussion content on the written communication channel is structured by the agenda. Each participant can, at any time, make written comments on the agenda (e.g. 
"In this proposal, it should be noted that....."). The oral contributions are included in the minutes by the assistant.

Questionnaires with prior discussion and feedback: The councilors complete an electronic questionnaire. To allow for qualitative input and to insure that City Council members think before they answer an electronic brainstorming precedes each question session. After a question session, there is immediate feedback to the participants and an oral discussion.

Active presentation of the system: In an active presentation, new city council members learn about the system and have the opportunity via brainstorming and evaluation to describe the actual issues of City Council work.

- Process intervention: Problem solving techniques and technology can intervene strongly into the traditional meeting process or can leave it largely unchanged. Thus, electronic minutes are low process intervention and computer supported workshops a high process intervention. Typically, the higher the process intervention, the more beneficially computer support can be, but the higher is the risk that the participants do not accept the process.

f) Characteristics of the outcome

- Success: A meeting is classified as successful, if the meeting initiators objectives are met. Our ultimate interest was to find out, what made computer support successful in council meetings.

We included only those characteristics in the framework that were different in the meetings, and left out those characteristics the were equal in all meetings. This gives us the opportunity to analyze the specific features of political meetings. But as the framework does not cover important potentials of GSS support used in the meetings (e.g. anonymous or parallel contributions) meeting success cannot be comprehensively explained by the framework's characteristics. Therefore meeting success must also be attributed to other ("standard") characteristics of computer supported meetings (see e.g. [Schwabe 1995]).

\subsection{Meeting evaluation}

At least two members of the Cuparla Team participated in all 17 meetings both in the preparation and the actual meeting. The sample is biased by the effort of the Cuparla Team to make computer supported meetings a success. This may not only have biased their evaluation, but also has influenced the composition of the sample: If a certain type of meeting turned out to be successful, we were apt to repeat supporting it thank if it was not successful. Consequently, we have less evidence to support cases of failure than cases of success.

All meetings were chauffeured by members of the Cuparla Team. We used the output generated by GroupSystems to analyze the meetings. It was, however, not possible to systematically gather specific input from the participants about the individual meetings. The evaluation is therefore heavily based on the interpretation of the Cuparla Team. This may not be as critical for factual information (such as number of participants, duration of the meeting or the technical stability) as for softer information (such as the sensitivity or the success of the meeting). To improve the reliability of their observations, the participating members of the Cuparla Team (successfully) strove for intersubjective agreement on their observations by discussing the meetings in the group and with the participating councilors. Thus, we have very rich data, but with a rather limited internal validity. 
Figure 2 summarizes the results. The meetings are clustered according to their purpose. A sequence of meetings (e.g. for requirements) is collapsed in one meeting, if they had one heading and one meeting built on the intermediate results of the others.

\begin{tabular}{|c|c|c|c|c|c|c|c|c|c|c|}
\hline $\begin{array}{l}\bar{\Phi} \\
\text { है } \\
\bar{\Xi} \\
\end{array}$ & $\begin{array}{l}\stackrel{D}{D} \\
\stackrel{D}{ \pm} \\
\stackrel{\mathbb{D}}{\Sigma}\end{array}$ & 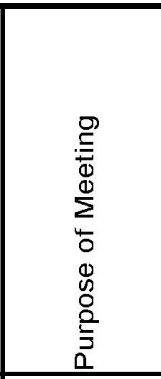 & 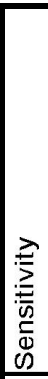 & 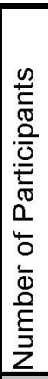 & 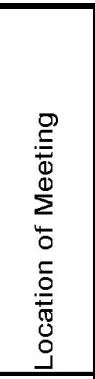 & 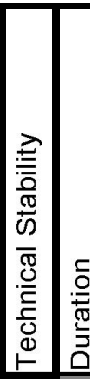 & 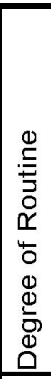 & 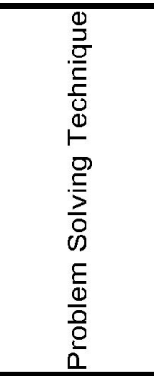 & 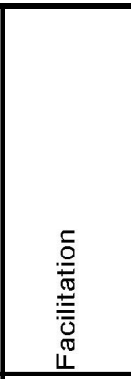 & 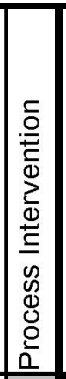 \\
\hline 1 & Primary Contact & Requirem. & & & Uni & & & active pres. & Cuparla & \\
\hline 2 & Primary Contact & Requirem. & & & Uni & & & active ores. & Cuparla & \\
\hline 3 & Primary Contact & Bequirem. & & & Uni & & & active ores. & Cuparla & \\
\hline 4 & Requirements Analvses & Requirem. & & & Uni & & & Workshop & Cuparla & \\
\hline 5 & Requirements Analyses & Requirem. & & & Uni & & & Workshop & Cuparla & \\
\hline 6 & Primary Measurement & Evaluation & & & City & & & Quest_\&Di. & Cuparla & \\
\hline 7 & Final Evaluation & Evaluation & & & City & & & Quest_\&Di. & Cunarla & \\
\hline 8 & Final Evaluation & Evaluation & & & City & & & Quest.\&Di. & Cuparla & \\
\hline 9 & Weekly Party Meeting & Fact.Meet & & & Uni & & & E.D+Eval & $\mathrm{GB}$ & \\
\hline 10 & Committee Meeting & Com.Meet. & & & City & & & Workshop & Cup $+\mathrm{GR}$ & \\
\hline 11 & Committee Meeting & Com. Meet. & & & City & & & Workshop & Cuparla & \\
\hline 12 & Preparation for Budget Neqotiations & Fisc.Plan. & & & Extern & & & Sim. Prot. & Cup+GR & \\
\hline 13 & Committee Meeting & Fisc.Plan. & & & City & & & E.D+Eval & $\mathrm{Cup}+\mathrm{GR}$ & \\
\hline 14 & Preparation for Budget Negotiations & Fisc.Plan. & & & City & & & Workshop & $\mathrm{Cup}+\mathrm{GR}$ & \\
\hline 15 & Preparation for Budget Neqotiations & Fisc.Plan. & & & City & & & Workshop & Cup+GR & \\
\hline 16 & Preparation for Budget Negotiations & Fisc.Plan. & & & Extern & & & Sim.Prot. & $\mathrm{GR}$ & \\
\hline 17 & Citizen Partizipation Meeting & Citiz.Part. & & & Extern & & & Workshop & Extern & \\
\hline
\end{tabular}

Symbols:

\begin{tabular}{|l|l|l|}
\hline \multicolumn{1}{|c|}{ Evaluation } & No. Participants & Duration \\
\hline high & $>20$ & $>=8$ hours \\
medium - high & $15-20$ & $4-8$ hours \\
medium & $10-14$ & $3-4$ hours \\
medium - low & $6-9$ & $1,5-3$ hours \\
low & $<5$ & $0-1,5$ hours \\
\hline
\end{tabular}

\section{Figure 2: Summary of the results}

Meeting

Purpose of Meeting

Sensitivity

Number of Participants

Location of Meeting

Technical Stability

Duration

Degree of Routine

Problem Solving Technique
Meeting Name

- Requirem. = gathering requirements for the design of Cuparla

- Evaluation = Evaluation of the project by project participants

- Fact. Meet. = weekly faction meeting

- Com. Meet. = regular committee meeting

- Fisc. Plan. = Fiscal Planning Meeting. Regular (yearly) meeting of a party or a working group to plan the fiscal year.

- Citiz. Part. = Citizen Participation in local issues

Extent of political sensitivity for the politicians

Number of participants (not including Cuparla team members), see scale above

- Uni = At the CATeam-Room of the University of Hohenheim

- City = in a room of the city hall

- External = anywhere else, not Uni and not City

Extent to which the system ran without problems

Total amount of time spent in meetings on the same topic, see scale above

Extent, to which this type of meeting is routine for the participants

- Active Pres. = Active Presentation

- Workshop = Workshop

- Quest.\&Di. = Questionnaire with discussion and feedback

- E.D.+ Eval. = Electronic Discussion and Evaluation

- Sim. Prot.= Simultaneous Protocol 
Facilitation

Process Intervention

Success
- Cuparla = Facilitation by a project team member of Cuparla

- $\mathrm{GR}=$ Facilitation by a politician (Head of Faction)

- Cup.+ GR = joint Facilitation, Cuparla and politician

Extent to which we changed meeting by using different moderation techniques

Success from the initiators point of view $=$ objectives were met.

\subsection{Analysis of meetings}

This section analyses the meeting evaluations. We will propose our results in the form of hypotheses. These hypotheses are first phrased in sentences. To make their relationship to the evaluation scheme transparent, we then rephrase them in a semiformal form. These results are based on efforts to implement GSS into council work. The hypotheses may not be applicable to later parts of the life cycle, i.e. for the routine use of GSS in daily council work.

\section{Result 1: GSS are easiest accepted in novel meetings:}

If $\left((\right.$ Task.purpose $=$ unfamiliar $)$ or $\left(\right.$ Context.Location $=$ unfamiliar $\left.^{7}\right)$ or $($ Process.routine $=$ low $\left.)\right)$ then (Outcome.success $=$ high)

Every meeting relating to the aims of the Cuparla project (i.e. "Requirements", "Evaluation") was successful, whereas only a part of the meetings relating to the aims of city councilors were successful. Several reasons may account for this: for one thing, a selection of participants for the meetings for the projects took place; whoever did not want to come, stayed at home. As, however, complete computer beginners took part in those meetings, this selection took place not only for those with computer knowledge; it also matters how receptive the participants are towards new ideas. Most of the meetings fulfilling the aims of the project took place at Hohenheim. The organizers had, in two respects, a home match: subjects were discussed with which they were familiar (and the city councilors unsure) and they were on home territory (whereas the city councilors had to leave their familiar surroundings). Since meetings have their own traditions and rituals which are frequently linked to particular subjects as well as to the material working environment, changes to unaccustomed surroundings and with unfamiliar subjects are brought about more easily. This is also confirmed by the observation that all the unsuccessful meetings (with the exception of the closed council meeting because it did not take place and which did not really fit into the project) had a high degree of routine. In these meetings the GSS interfered with the traditional procedures. In the unsuccessful meetings procedures were changed extensively.

The utilization of the CATeam for purposes that were novel for the city councilors in an unfamiliar context, has its drawbacks however. The city councilors have a better recollection of the meetings which dealt with the aims of the city council than of the meetings which dealt with the aims of the project. This means: for sustained success (and not just one successful meeting) meetings have to be computer-supported with the aims of the city council in mind and they have to take place in familiar work surroundings for only then the councilors can appropriate the technology to their work.

Result 2: Process routine and process intervention influence the meeting success in the following manner: The more routine a meeting is the smaller can be process interventions. If $(($ If Process.routine $=$ increasing $)$ then $($ Process.intervention $=$ decreasing $))$ then

(Outcome.success $=$ increasing)

\footnotetext{
${ }^{7}$ With one exception: Meeting 9
} 
Experience indicates that one should only work with small interventions in meetings with a high degree of normal routine, as for example, with the simultaneous minute-taking. All the meetings where the process interventions were small met with success. This is of course understandable since the normal meetings (committee, city council, party political meetings or working parties) are sacred for city councilors. Any change can lead directly to a shift in the balance of power.

Major changes in the proceedings enhance the productivity of the meetings more than the introduction of minor ones. Therefore meetings ought to be carried on with major changes in the proceedings but preferably, however, in areas where little routine exists. Once the city councilors have grown accustomed to computer-support, the process interventions can increase in high routine areas.

\section{Result 3: Partnership in facilitation is needed in sensitive meetings}

If $($ Task.sensitivity $>$ low $)$ then $($ Success $($ Process.Facilitator $=$ external implementor + councilor $))>$ (Success $($ Process.Facilitator $=$ councilor or external implementor $)$ )

Sensitive meetings require both specific knowledge about the participating group and knowledge about the design of the problem solving techniques with GSS. Typically a member of the group possesses the first and a trained facilitator the latter. If both team up in facilitation, meetings tended to be at least partially successful; if only one took up the responsibility, meetings tended to be less successful.

If a single meeting is the objective of the user, a team of facilitators is $\mathrm{dk}$. If however the selfsustaining implementation of GSS is the more overarching objective, the dependence on an external facilitator poses a serious problem [Briggs et al. 1999]. The facilitator is not always at hand and may be expensive. Furthermore the group may not tolerate externals in their most sensitive meetings.

\section{Result 4: Meeting success increases with the number of participants and the duration of the meeting \\ If $($ Group.participant number $=$ increasing $)$ and $($ Process.duration $=$ increasing $)$ then \\ (outcome.success $=$ increasing).}

Conventional meeting productivity tends to decrease with group size because process losses increase (cf. e.g. [Nunamaker et al. 1991]). This is not as much the case with computer supported meetings. The cost function of computer supported meetings differs from the cost function of non-supported meetings (Figure 1). 


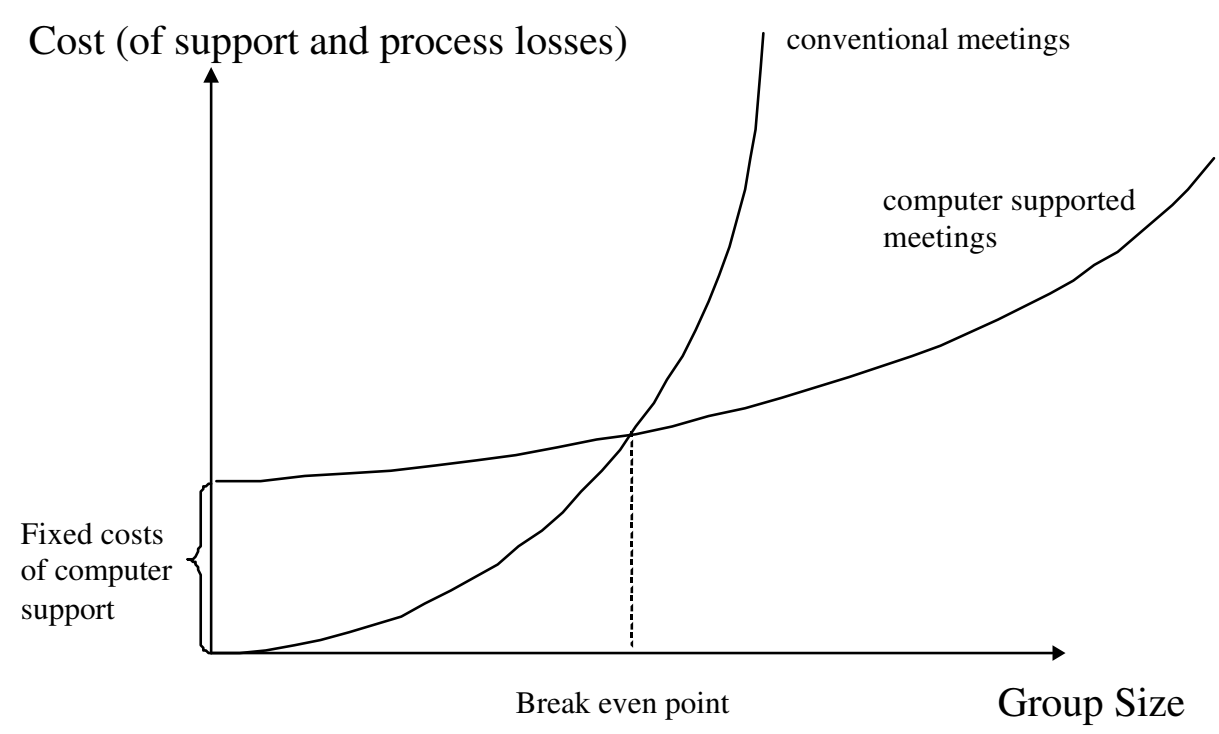

\section{Figure 3: Cost function of computer supported meetings and conventional meetings}

Meeting costs consist of the cost for support (e.g. set-up of the meeting room) and the cost of process losses (e.g. the cost of production blocking or low participation). Computer support has a large fixed cost block for set-up and meeting preparation, but the cost function only increases moderately with group size (due to increasing support cost and process losses). Conventional meetings have a very low base of fixed cost, but the cost function rises much steeper mainly due to increasing process losses. There is a break even point where the two functions intersect, i.e. where it does not make any difference, if the meeting is computer supported or not. If the group size is larger than the break even point, computer support is economical; if it is smaller, conventional meetings are more economic. The cost function does not only depend on group size, but also on other meeting characteristics (task, meeting duration...). Thus, the break even point may vary with the meeting type. We would see the break even point for a typical council meeting at about seven participants. This limit poses a serious challenge for the GSS implementation in city councils as it effectively excludes small parties (which typically have $3-5$ members) from support in their party meetings. If larger parties have the opportunity to appropriate GSS in their internal meetings they may also be in advantage in computer supported committee meetings. This may lead to a resistance of the small parties to use computer support in official council meetings.

The relationship between group size and cost can be used to explain the relationship between group size and meeting success: Meetings were successful if the meeting objectives were met. As the traditional meeting is the norm for what people ${ }^{8}$ expect from meetings, meetings were regarded to be particularly successful in the eyes of the initiators, if the cost/benefit ration was better than they had expected.

The two smallest supported meetings had each only five participants. One meeting (a part of the Cuparla requirements workshops) was a success. Here the participants built on the results of previous meetings with more people having taken part. The only isolated small meeting owed its

\footnotetext{
${ }^{8}$ At least the city councillors.
} 
failure to the fact that utilization of technology was not worthwhile with just five participants. Each participant had in any case sufficient opportunity to speak and the technology did little to solve their collaboration problems.

A similar cost argument holds true for meeting duration. The longer a meeting lasts, the more important are the decreased processes losses of computer supported meetings and the less important are the high fixed costs for system set up and meeting preparation. Very successful supported council meetings had many participants and lasted over several days (e.g. the Local Agenda 21 workshop), while there is a more mixed picture for shorter meetings with fewer participants, if the meeting was initiated by the councilors.

\section{Result 5: GSS must be ready-at-hand to be useful}

If $($ Technology.stability $=$ decreasing $)$ then $($ Outcome.success $=$ decreasing $)$

In some meetings, instability of the GSS lead to interruptions in the meeting process. Low GSS stability once even lead to a complete failure of the meeting (meeting 11). Actual instability leads to a decreasing confidence of the participants; potential instability leads to a decreasing confidence of the persons responsible for the meeting process (i.e. the facilitator). The potential technological instability of the mobile GSS was a major reason, why we supported only 17 council meetings.

Ready-at-hand also means that the councilors have to know how to use the technology, particularly in sensitive meetings. In these meetings the city councilors are either standing in the glare of publicity (the electorate!) or their aims are so confidential and sensitive that outsiders are only tolerated as a last resort. Because of the confidentiality of meetings and the pressure of time, any interruptions are undesirable. It would be a considerable distraction if councilors had to be instructed in the use of the technology during the meetings and then missed out on what was happening. This was the reason given by mayor for declining computer-support for a plenary strategy workshop in an early stage of the Cuparla project: only one part of the city council possessed computer training at this point in time. He said, as soon as every city councilor could cope with the notebook, he would welcome computer-support.

Finally, hypotheses already established from previous research on meetings are reinforced by these meetings [cf. Lewe 1995, Schwabe 1995, Gräslund 1998]: In each case anonymity contributed to an atmosphere of frankness and was welcomed by the participants. Working in parallel enhanced work productivity and group memory improved the reuse of meeting results.

\subsection{Conclusions for the implementation of GSS in councils}

Our aim of a GSS implementation in city councils is the self-sustaining use of the GSS in daily council work. While the Cuparla project has been successful in implementing an asynchronous Lotus Notes groupware into daily council work, the stage of self-sustaining use of GSS has not been reached yet. Reaching the stage of self-sustenance is notoriously difficult with GSS (see e.g. [Briggs 1999]) and it is still an open question, how to achieve it. We will now propose a four stage process model for implementation based on our analysis of council meetings (Figure 4). This concept is based on the observation that dealing with meeting sensitivity (see result 3) and applying the right degree of process intervention (see result 2) are most difficult. Therefore they are the key parameters. 


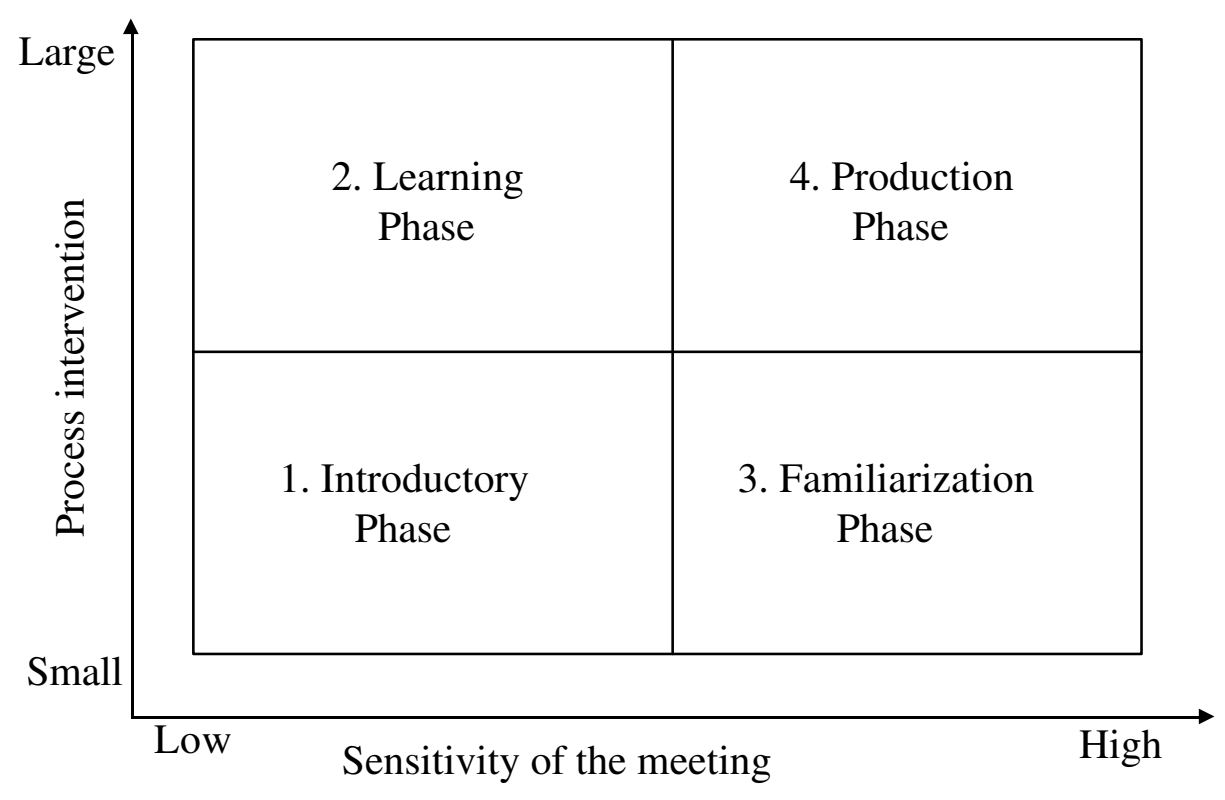

\section{Figure 4: Phases of GSS implementation}

The introduction of technology into a formal decision-making body should begin in less sensitive meetings and with minor changes of process ("introductory phase"). In these meetings the participants make themselves familiar with the technology. Basic knowledge about further possibilities for computer-support as well as the necessary confidence to risk further utilization of technology is developed. A thorough requirements analysis is a good example of such a meeting. As a second step, meetings are suggested where there is only a small degree of sensitivity and major changes of procedure. In this "learning phase" the group gets to know the extensive potential of the technology and learns to function as "secondary facilitator". A workshop with the participation of (trusted) citizens for example suits this purpose (see section 4.3). A third step leads to the adaptation of technology for the daily business of the meeting ("familiarization phase"). Changes of procedure in this sphere should be kept small and simple since meetings (e.g. formal committee meetings) are normally protected by a large number of rules and rituals. These rules and rituals stipulate the way in which the meeting must be conducted. Without the confidence in the advantages of electronic support in meetings, city councilors will not relinquish their conventional methods of conducting business. An example is a closed budget meeting (see section 4.1).

Nevertheless, technology can realize its full potential by being utilized in regular formal meetings of the city council ("production phase"), e.g. committee meetings (see section 4.2) These regular meetings account for more than $90 \%$ of the council meetings. One has to include these standard meetings in order to reach the critical mass of usage experience necessary for a self-sustaining use. It requires a large process intervention to make these meetings productive in the long run and these meetings are highly sensitive. Thus the majority of all meetings belong to the high-sensitivity, highprocess-intervention segment. In the Stuttgart City Council the productive phase has not yet been reached, but the hope remains that the future utilization of electronic support for meetings will make them more open, more productive and more democratic. For the time being, it looks as if this stage can only be reached by a gradual process of increasing know-how and confidence. 


\section{Acknowledgement}

The authors would like to thank the Cuparla Team (particularly Andreas Majer, Arnd Klein, Birgit Schenk, Bernd Vöhringer, Dieter Hertweck, and Udo Heikenwälder) who made Computer Support to councils possible. Arnd Klein also provided valuable input to the analysis of the computer supported council meetings.

\section{Literature}

Bever, M. et al.: Poliwork - Telekooperation und Dokumentenverwaltung am persönlichen Arbeitsplatz. In Krcmar, H.; Lewe, H.; Schwabe, G.: Herausforderung Telekooperation, Springer Berlin et al. 1996, p. 17-34.

Borgmann, T.: Nur Aufwandsentschädigung und Sitzungsgeld. In: Stuttgarter Zeitung Online vom 20.09.1997, Lokalteil.

Briggs, R. et al.: A Technology Transition Model Derived From Qualitative Field Investigation of GSS Use Aboard the U.S.S. CORONADO. Working Paper of the Center for the Management of Information University of Arizona 1999, appears in JMIS 1999.

Dennis, A. et al. (1998): Information technology to support electronic meetings. In: MIS Quarterly Vol. 12, Nr.4 (Dezember 1988), p. 591-624.

Dienel, P.: Die Planungszelle 2. Auflage, Westdeutscher Verlag, Opladen 1991.

Dietel, C.; Schneider, G.; Schweitzer, J.: Polivest Integrierte Televerwaltung. In: Mambrey, P.; Streitz, N.; Sucrow, B.; Unland, R.: Rechnergestützte Kooperation in Verwaltungen und großen Unternehmen; Tagungsband zum Workshop der GI-Fachgruppe 5.5.1 und der GI-Fachbereiche 6 und 8 im Rahmen der GI Jahrestagung 1997, Essen, p. 188-205.

Engel, A.; Kaack, H.; Kaiser, S.: Teamarbeitsräume zur Unterstützung verhandlungsorientierter Vorgangsbearbeitung. In: Mambrey, P.; Streitz, N.; Sucrow, B.; Unland, R.: Rechnergestützte Kooperation in Verwaltungen und großen Unternehmen; Tagungsband zum Workshop der GIFachgruppe 5.5.1 und der GI-Fachbereiche 6 und 8 im Rahmen der GI Jahrestagung 1997, Essen p. $163-177$.

Klebert, K.; Schrader, E.; Straub, W.: Moderationsmethode, Windmühle GmbH Hamburg 1985.

Krcmar, H.: Computerunterstïtzung für die Gruppenarbeit - Zum Stand der Computer Supported Cooperative Work Forschung. In: Wirtschaftsinformatik Vol. 34 Nr. 41992 p. 425-437.

Krcmar, H.: Informationsmanagement, Springer; Heidelberg u.a. 1997.

Lewe, H.: Computer Aided Team und Produktivität - Einsatzmöglichkeiten und Nutzenpotentiale. Gabler, Wiesbaden 1995.

Lewe, H.; Krcmar, H.: GroupSystems - Aufbau und Auswirkungen. In: Information Management, Vol. 7, Nr. 11992 p. 32-41. 
Lyytinen, K.; Maaranen, T.; Knuuttila, J.: Unususual business or business as usual - an investigation of meeting support requirements in multilateral diplomacy. Arbeitspapier WP-26, University of Jyväskyla, Finnland August 1992.

Nunamaker, J. et al.: Electronic meetings to support group work. In: Communications of the ACM, Vol. 34, Nr. 7( July 1991), p. 40 - 61.

Reichwald, R. et al.: Telekooperation, Springer Berlin et al. 1998.

Schenk, B.; Schwabe, G.: Die elektronische Zukunftskonferenz - ein Beispiel aus dem Stuttgarter Agenda 21-Prozeß, Arbeitspapier des Lehrstuhls für Wirtschaftsinformatik der Universität Hohenheim, Stuttgart 1998.

Schnelle, E.; Schnelle, W.: Metaplan - Das Geheimnis der Wolke. In: Management Wissen, No. 12 (1984), p. 17-33.

Schuler, D.: New Community Networks - wired for change, New York 1996.

Schwabe, G., Hertweck, D.; Krcmar, H: Partizipation und Kontext bei der Erstellung einer Telekooperationsumgebung. In: Jarke, M.; Pasedach, K.; Pohl, K.: Informatik 97 - Informatik als Innovationsmotor, Springer, Heidelberg. et al. 1997, p. 370-379.

Schwabe, G., Vöhringer, B.: Computerunterstützung der Parlamentsarbeit - ein Baustein zum Umbau der Verwaltung. In: Verwaltung und Management Vol. 4, Nr. 3, 1998, p. 140-147.

Schwabe, G.: Computerunterstützte Sitzungen. In: IM- Information Management Vol.9, Nr. 3 (1994), p. 34-43.

Schwabe, G.: Objekte der Gruppenarbeit - ein Konzept für das Computer Aided Team, Gabler, Wiesbaden 1995.

Schwabe, G.: Pilotierung von Telekooperation. Habilitationsschrift an der Universität Hohenheim, Stuttgart 1998.

Schwabe G.: Informationsmanagement für den Gemeinderat: In: Hummeltenberg, W.: Information Management for Business Intelligence, Proceedings der Frühjahrstagung Wirtschaftsinformatik `98, Vieweg 1998b, p. $55-67$.

Schwabe, G.: Understanding and Supporting Knowledge Management and Organizational Memory in a City Council. In: Hawaii International Conference on System Sciences 1999 (HICSS99), CDROM, 12 pages.

Schwabe, G.; Krcmar, H.: CSCW Werkzeuge. In: Wirtschaftsinformatik Vol. 38, Nr. 2 (April 1996) p. 209-224.

Schwabe, G.; Krcmar, H.: Der Needs Driven Approach - Eine Methode zur Gestaltung von Telekooperation. In: Krcmar, H.; Lewe, H.; Schwabe, G.: Herausforderung Telekooperation Proceedings der DCSCW 96, Springer, Heidelberg u.a. 1996c. 
Schwabe, G.; Krcmar, H.: Telearbeit im Stuttgarter Stadtparlament - erste Erfahrungen. In: Telearbeit 96. Hüthig Verlag Heidelberg 1996b.

Van Gundy, A.: Techniques of structured problem solving, 2. Auflage, Van Nostrand Reinhold, New York 1988. 